\title{
THE ROLE OF CHARITABLE ACTIVITY IN THE FORMATION OF VILNIUS SOCIETY IN THE 14TH TO MID-16TH CENTURIES
}

\author{
S.C. Rowell
}

ABSTRACT This article examines the development of charitable activity in the city of Vilnius and elsewhere in the Grand Duchy of Lithuania before the middle of the sixteenth century by studying the foundation of almshouses to care for the poor and destitute and foster the memory and salvation of pious benefactors. Almshouse foundations developed from increasing forms of practical piety within the GDL from the late fifteenth century, following earlier west European and Polish models. The first, dedicated to traditional patrons of such institutions, St Job and St Mary Magdalene, was founded by a Vilnius canon and medical doctor, Martin of Duszniki with the support of the monarch, Sigismund the Old, and his counsellors between 1518 and 1522. The almshouse swiftly became an established part of the city's sacral topography. The fashion was adopted by Eastern Orthodox parishes in Vilnius too, and later spread to other confessional groups. Twelve charters are published for the first time in an appendix.

Christian charity in public spaces flourished throughout Catholic Europe during the 13 th to 15 th centuries ${ }^{1}$. Indeed, the first charitable intitutions for the poor are known in England from the tenth century. It behoved the bishop elect on taking his oath of office to protect the poor and the sick ${ }^{2}$. Providing lodging and food for the deserving poor over time became the function of almshouses, hospitalia. While medical attention may have featured in the services they offered, they were not modern hospitals - the wealthy sick were treated in their own homes by physicians privately hired. In Western and Central Europe, the building of hospices has been seen as a sign of urban development (along with a mendicant friary or the foundation of a parish church network) and civic religious

${ }^{1}$ M. Rubin, 'The Poor', Fifteenth-century attitudes. Perceptions of society in late medieval England, ed. R. Horrox (Cambridge, 1994), pp. 169-182.

2 R.M. Clay, The Medieval Hospitals of England (London, 1909), chapter one. 
life ${ }^{3}$. Hospitals or hospices (almshouses) were religious foundations with spiritual purposes determined by their founders, and in return for accommodation and food, their inmates were expected to pray for their benefactors. The city hospice was a matter of civic pride. While the halcyon days of hospice-building were perhaps the 14th and 15th centuries, to meet with a decline under pressure from Protestant zealots, who objected to their religious motivation, notably their role as a type of chantry, they began to flourish in 16th-century Vilnius, reaching their heyday (according to the accidental survival mostly of the later written records) in the 17th and 18th centuries, when several Christian communities (not only Catholic, but also Orthodox and Protestant ones) maintained almshouses, which gradually underwent medicalisation to become the forerunners of more modern-looking 'hospitals's.

The sources available to historians studying charitable institutions is rich and varied. Hospitals produced their own rules as to how inmates were to behave and how they were to be supported. Hospital accounts and the records of the urban authorities which often financed the care of the poor and sick from religious devotion reveal much about the lives and aspirations of both donors and recipients ${ }^{5}$. Needless, alas, to say, such a wealth of sources is not available for those interested in the development of hospices in the GDL. However, we must resist the temptation to deny a priori the existence of such institutions, because the extant sources (charters preserved in the Lithuanian Metrica and the chapter records of the Diocese of Vilnius) are not so prolific as the records of central European bishoprics. Indeed, lack of care in sifting the sources which do survive has led to certain misinterpretations in the past. Thus

${ }^{3}$ M. Slon, 'Fundacje szpitalne władz komunalnych jako centra kultu miejskiego', Ecclesia et civitas. Kościót i życie religijne w miéscie średniowiecznym [Colloquia mediaevalia Varsoviensia III], ed. H. Manikowska, H. Zaremska (Warsaw, 2002), pp. 361-371. Cf the studies of Cambridge charity - M. Rubin, Charity and community in medieval Cambridge [Cambridge Studies in Medieval Life and Thought, 4th series, 4] (Cambridge, 1987) - and Bruges - A. Brown, Civic ceremony and religion in medieval Bruges c. 1300-1520 (Cambridge, 2011), esp. pp. 195-213. On Wrocław, see M. Slon, Szpitale średniowiecznego Wrocławia (Warsaw, 2000).

${ }^{4}$ J. Maroszek, 'Wileńskie przytułki-szpitale w XVI-XVIII w.', Cała historia to dzieje ludzi... Studia z historii społecznej ofiarowane prof. Andrzejowi Wyczańskiemu $w$ 80-ta rocznice urodzin i 55-lecie pracy naukowej, ed. C. Kuklo, P. Guzowski (Białystok, 2004), pp. 191-218.

5 See for example Rubin, Charity and community or more appropriately for the Central European experience, M. Slon, 'Średniowiecne rachunki szpitali wrocławskich’, Kwartalnik Historyczny, 105 (1998) 2, pp. 17-32. 
the list of hospital charters recorded in a 17th-century inventory of St Mary Magdalene's Church gives the impression that the endowment began in 1502 with a document of King Sigismund (regnant 1506-1544) which may form the basis for the claim that Grand Duke Alexander (1492-1506) founded the hospice ${ }^{6}$.

\section{Cases from Poland and Central Europe}

In the 14th century hospices were dependent mainly on religious orders, but as we approach closer to the 16th they often become associated with urban communities. According to Archbishop Jan Łaski's Liber beneficiorum, in the first quarter of the 16th century there were 31 almshouses in 28 parishes within the vast Archdiocese of Gniezno; in the Diocese of Poznań in 1510, out of 406 parishes, 21 had an almshouse, referred to as Domus pauperum, domus infirmorum. In some cases, an almshouse church might be founded some time before an actual poor house was built. The almshouse often was run by an especially appointed priest (prepositus, provisor, procurator), often assisted by a factor to look after the institution's property, and overseers both male and female. Almshouses developed a tendency to become a clerical benefice just like any other. The prepositus was responsible for both the spiritual care of the inmates and the upkeep of the building and its property - administratio spiritualium, regimen temporalium ${ }^{7}$.

Hospices were dedicated to various holy patrons. The most common dedication was to the Holy Ghost, often connected with the hospitaller order of the Holy Ghost based in Rome at the Saxon Hospice and active in Poland from the early 13th century ${ }^{8}$. This establishment was associated with the Vilnius Franciscans from 1456 (see below). The most common dedications were to the Holy Trinity, Holy Cross, Ss George, Leonard, Valentius, Laurence, Michael, Mary Magdalene, Elisabeth and Gertrude (the latter two saints were especially popular in the lands of the Teutonic Order).

${ }^{6}$ MAVB F43-680, published in: V. Drèma, Vilniaus bažnyčios. Iš Vlado Drèmos archyvu (Vilnius, 2007), p. 568.

${ }^{7}$ In general see E. Wiśniowski, 'Rozwój organizacji parafialnej w Polsce do czaśow reformacji', Kościół w Polsce, tom pierwszy: Średniowiecze, ed. J. Kłoczowski (Kraków, 1968), pp. 346-359; Szpitatnictwo w dawnej Polsce, ed. M. Dąbrowska, J. Kruppe (Warsaw, 1998).

${ }^{8}$ K. Antoniewicz, 'Zakon Ducha świętego de Saxia w Polsce średniowiecznej', Nasza Przeszłość, 23 (1966), pp. 169-173. 
Charity in Lithuania began with the religious orders, viz. the Franciscans and their fraternities, and was propagated by the secular clergy too. The parish church of St John in Vilnius had a confraternitas pauperum by the mid-15th century, when the Unionist Cardinal Isidore granted an indulgence for those visiting the church on the feasts of Holy Trinity, Corpus Christi and the Birthday of St John the Baptist ${ }^{9}$. Other indulgences had been given several decades earlier for those who accompanied the parish priest as he took the Blessed Sacrament to the city's sick ${ }^{10}$. The late-15th century saw popular devotion to the Man of Sorrows (Imago Pietatis), known to Lithuanians as Rüpintojèlis. The Franciscan Conventuals offered membership of an international charity fraternity, the Hospitale Sancti Spiritus based in Rome, to which Lithuanian nobles belonged directly in the $1490 \mathrm{~s}^{11}$. The parish and convent fraternities probably created the tradition of charitable self-help and its off-shoot, the provision of aid for the less fortunate, often connected with reciprocal services - the prayers of the poor.

The donation of alms to the poor had a clear model and protector in the rulers of Lithuania, as we can see from the surviving grandducal account books, even though such almsgiving was seasonal and not directed as a specific, more or less permanent community of poor people. Grand Duke Alexander distributed alms to the poor during the great liturgical feasts ${ }^{12}$.

Almshouse are a feature primarily of the European urban landscape. Towns have people who fall out of the safety net of provision by small communities and families, when personal need must be met by more broadly constituted institutions. Hospices provide relief in

${ }^{9}$ Mantua, 15 Nov. 1459, ms Berlin, GStAPK, Zawtowt Sammlung Nr 5 (photographic copy made by Z. Ivinskis for K. Jablonskis: MAVB, F256, b. 2588). The indulgence was approved by Bishop Nicholas of Vilnius and later confirmed by Cardinal Frederyk Jagiellonczyk. It was at this time that Isidore granted an indulgence to the Vilnius Franciscans (for those visiting during the great Marian feasts - Kodeks dyplomatyczny katedry i diecezji wileńskiej [KDKDW], ed. J. Fijałek, W. Semkowicz (Kraków, 1948), No 231, pp. 256-258). It is unclear whether this fraternity is the same as that mentioned in indulgences from 1430.

10 S.C. Rowell, 'XV a. LDK vyskupu atlaidos raštai Vilniaus katedrai bei miestui. Tekstas ir kontekstas', Lietuvos pilys 3, (2008), pp. 94-104.

${ }^{11} K D K D W$ No. 225, pp. 250-251, Vilnius, 11 Sept. 1456.

${ }^{12}$ Lietuvos didžiojo kunigaikščio Aleksandro Jogailaičio dvaro saskaitu knygos (1494-1504), ed. D. Antanavičius, R. Petrauskas (Vilnius, 2007), pp. 212, 214, 216 , 218, 220, 234, 266, 268, 270, 272, 282, 306; U. Borkowska, Dynastia Jagiellonów $w$ Polsce (Warsaw, 2011), pp. 400-404. 
return for services - prayers for living and dead benefactors - and a certain amount of social control - attendance at Mass, participation in the Sacraments, and a requirement at least to provide a veneer of the decent and godly life. In Lithuania hospices were founded in parishes by patrons who would also build churches, chantry chapels and in smaller numbers, hospitalia - such as the Ilinicz patrons of Zelva parish and the Ss Job and Magdalene hospice in Vilnius. There were hospices in Kaunas, Grodno (Holy Trinity, founded 16 February 1553) ${ }^{13}$. Daugai had a church and hospice endowed by Queen Bona 18 June $1555^{14}$.

Lay piety in forms of devotion to the Blessed Sacrament, the cult of the Man of Sorrows and the Five Holy Wounds, the building of chantry chapels and parish churches, the application for papal indults including the right to choose a confessor or own a portable altar, membership of church fraternities which looked after the material and spiritual needs of their members living and dead (from memorial masses to financial loans) increased dramatically in the GDL among both Catholic and Orthodox subjects at the turn of the 16th century. By 1517, Catholic Vilnius burghers sponsored the printed publication of Ruthenian translations of Holy Writ from the Polotsk doctor Frantisek Skoryna. One of the first published translations was the Book of Job, the archetypal sufferer. ${ }^{15}$ Could it be that this publication increased, or at least reflected existing burgher awareness of the scriptural injunctions to succour the poor? It may be more than a coincidence that the first Vilnius almshouse would be dedicated to Job and the penitent comforter of Our Lord, St Mary Magdalene ${ }^{16}$. Outside the capital noble patrons were incorporating hospices into their parish foundations as early as 1508. It was in that year while resident at their house in Vilnius on the banks of the Vilnele that Anna and George Ilinicz made endowments in Zelva for a chantry, a school and an almshouse, granting the latter, should it last and not be deserted, an annual donation for the paupers of two barrels each of rye and corn and a quarter of a barrel of beans, plus one pig.

${ }^{13} L M 70$, p. 69v - prepositus Baltramiejus Kunigas.

${ }^{14} \mathrm{Cz}$ 1777, fos 215-216, pp. 509-511.

${ }^{15}$ S.C. Rowell, 'Vernacular Translations of Scripture in England and Lithuania before the Seventeenth Century', Lithuanian Historical Studies 16 (Vilnius, 2012), pp. 85-95.

${ }^{16}$ By way of comparison, we might note the foundation of a hospital in Wrocław in 1517 by the Bernardines, dedicated also to Job - Slon, Szpitale, p. 272. 
The scholars, by way of comparison, were to receive three barrels of rye and corn, one of beans and two pigs. The hospice was to be governed and ruled by the parish priest ${ }^{17}$.

The first known Vilnius almshouse was founded for the support of ten paupers in 1514 by the Vilnius canon and doctor of medicine Martin of Duszniki ${ }^{18}$. As in many cases of almshouse foundation, the process of actually building a poor house was a rather longer affair than might at first seem likely. It was towards the end of December 1518 in Brest Litovsk that Martin obtained practical support from his master Grand Duke Sigismund for his endeavour (bonum et laudabile propositium) in the form of a grant of land opposite the episcopal palace in Vilnius Castle on the banks of the Vilnele ${ }^{19}$.

The royal endowment was witnessed by an array of leading Lithuanian noblemen, as one might expect. Many of these witnesses made their own donations to the proposed hospice of Ss Job and Mary Magdalene over the following months and years. Before his death in April 1519, Bishop Albert Radvila granted a boggy, uninhabited patch of episcopal land beneath the castle between the houses of Klocko and Canon Albinus. This gift was not recorded in writing at the time, but was confirmed by Albert's successor John of the Lithuanian Dukes after consultation with the cathedral chapter in January 1522. Bishop John noted that it was his pastoral duty to take measures to see that the paupers did not become corrupted by various illnesses, hunger or cold without paternal provision and thus perish ${ }^{20}$.

Bishop Albert's brother, Nicholas Radvila, chancellor of the GDL and palatine of Vilnius made his own contribution to the almshouse in July 1519, offering a tithe of all grain from his manor at

${ }^{17}$ Biblioteka XX. Czartoryskich - see Appendix No 11.

18 The date 1514 is given (without documentary reference) by J. Kurczewski, Biskupstwo wileńskie od jego założenia az do dni obecnych, zawierajace dzieje $i$ prace biskupów i duchowieństwa djecezji wileńskiej oraz wykaz kościotów, klasztorów, szkót i zakładów dobroczynnych i społecznych (Vilnius, 1912), p. 357; for brief notes on the biography of Canon Martin, see Lietuvos kataliku dvasininkai XIV-XVI a., $[L K D]$, ed. V. Ališauskas, T. Jaszczolt, L. Jovaiša, M. Paknys [Bažnyčios istorijos studijos II] (Vilnius, 2009), No 1272, pp. 227-228. For an outline history of the Vilnius almshouses, see Maroszek, 'Wileńskie przytułki-szpitałe', pp. 191-218, here pp. 194-195.

${ }^{19}$ MAVB, F43-203, p. 294 - see Appendix No 7.

${ }^{20}$ See below, Appendix No 7; for the death of Bishop Albert, see Polski stownik biograficzny 30 (1987), p. 377. 
Buivydiškès to the north of Vilnius ${ }^{21}$. In August of the same year Gregory Astikas, son of the palatine of Trakai, vowed a similar tithe from his estate at Suderve, near Buivydiškès to the paupers of St Job's ${ }^{22}$. In September the palatine of Polotsk, Petras Kiška, offered a tithe of field grain from his manor in the hills beyond the mill owned by the Vilnius palatine. All these men were grandees, patrons of several ecclesiastical institutions and holders of high office. They were also witnesses to the royal endowment of Martin's hospice and had residences in Vilnius. So too was George Ilinicz, lord lieutenant of Brest, whose wife Anna had founded a hospice in their parish at Zelva some dozen years before Ilinicz granted St Job's ten barrels of rye and ten shanks of pork from his manor at Dworzyscze in the Lida District annually in April 1522. This donation may have been inspired further by the fact that Canon Martin had provided the marshall with purple silk to adorn the tomb of Anna Iliniczowa for a year on condition that afterwards the fabric would be handed over to the Hospice of St Mary Magdalene. The year of mourning elapsed in October 1522, judging by the Vilnius Chapter records ${ }^{23}$. Less tardy in endowing the poor was the royal secretary Paul Naruszewicz, who on 23 January 1520 granted four barrels of rye annually from his Ašmena estate south of the capital ${ }^{24}$.

In January 1521, Martin obtained from the papal legate Zaccaria Ferrari an indulgence of ten years and ten Lents for members of the Fraternitas Misericordie in his 'oraculo extra muros ab ipso Martino condendo' (in the hospice - house of prayer - he was to build beyond the castle walls) who put their hands to burying dead paupers in the city of Vilnius ${ }^{25}$.

${ }^{21}$ Appendix No 2.

22 Appendix No 3.

${ }_{23}$ Vilnius, MAVB F43, b. 210, Acta Capituli Vilnensis [ACV], t. 1, p. 54, Kurczewski, Kościół III, p. 13.

${ }^{24}$ Appendix Nos 6,5.

${ }^{25}$ Cum Martinus artium doctor, canonicus Vilnensis nobis ... supplicaverit, quatinus fraternitati misericordie in oraculo extra muros ab ipso Martino condendo,... ut ... indulgentias ... christifidelibus manus adiutrices pro sepeliendis pauperibus mortuis, qui.. per civitatem Vilnensem moriuntur porrigentibus, concdere dignaremur - MAVB F3-89, 25 Jan. 1521; registered by R. Jasas - Pergamentu katalogas (Vilnius, 1980), No 244, p. 100. A fortnight earlier (10 Jan. 1521) the legate had issued an indulgence at the request of Albertas Goštautas for his Confraternity of the Assumption in his parish foundation in Geranony - Sammlung Zawtowt 17. 
In May 1522, Jan Hlebowicz, the marshall of the grand-ducal court, and his wife Anna granted a tithe from their lands at Paneriai $^{26}$. That same year Canon Martin negotiated with the Vilnius chapter over the boundaries and control of and improvements to the plot of land, where the canons also intended to build their bath house $^{27}$. A year later St Job's had its plot of land and controlled the area from its gates as far as the bridge which it had built to get to the river (the land was a marsh), while the provisor of the hospice, Canon Martin, promised to maintain canals to improve access across the land to the castle for the canons ${ }^{28}$. When Canon Jan Filipowicz died in February 1524 he left his house known as Ostra next to the hospice to the chapter which rented it out to the Vilnius apothecary Matthias ${ }^{29}$.

According to Maroszek, apparently in the 1520 s one Mme Dydulewiczowa donated her commercial estate farm at Niewiaszowicze to the hospice (this may be the same Didulevičiene who in 1538 sold land near Suderve to the hospice provisor, Stanislaw Dambrowka - see below) and a similar gift at Witany was made by Mikołaj Fedorow ${ }^{30}$.

Thus, by 1525 the hospice was fixed in the city's geography (surrounded by the houses of canons, noblemen and burghers, beside a small bridge it built over the Vilnele,, making improvements to its marshy land) and also in the urban sacral topography. In that year, it was decided that cathedral processions on the Rogation days (the Monday, Tuesday and Wednesday before the Ascension of Our Lord) would lead to the Holy Ghost Church of the Dominicans on the first day, to St John's on the second, and on the third day to the Hospice of SS Job and Mary Magdalene ${ }^{31}$.

Canon Martin had an eye for consolidating his property, as in 1526 when he bought up tithes from two boyar estates in the Kernave area with the permission of the local parish priest Erasmus Eustchii ${ }^{32}$.

${ }^{26}$ MAVB, 43204 fo. $144 \mathrm{v}-145$.

${ }^{27}$ ACV, t. 1, p. 56, Kurczewski, Kościól zamkowy, p. 14.

28 Ibid, p. 65 and 17.

${ }^{29}$ Ibid, p. 67 and 18. On the apothecary, see R. Ragauskiene, 'Vaistininkai XVI a. Vilniuje', Vilniaus istorijos metraštis 1 (2007), p. 33, 38. Matthias along with the hospice factor Sebastian witnessed Stanislaw Dambrowka's 1536 land agreement with Mark Lepkowski - see Appendix no. 9.

${ }^{30}$ Maroszek, 'Przytułki-szpitałe', p. 195 and n. 18.

${ }^{31}$ ACV, t. 1, p. 101, Kurczewski, Kościól zamkowy III, p. 27.

32 Appendix No. 8. 
The social make-up of hospice patrons also widened in a trickledown effect of spiritual economy. In 1538, Darata Didulevičienè ackowledged that the Provisor of the St Mary Magdalene Hospice Stanislaw Dabrowka (who in July 1536 consolidated the hospice's land holdings by exchanging land with the nobleman Mark Lepkowski near the almshouse) bought up arable land and hay meadows in the Suderve area which had been mortgaged by her late husband Motiejus to the Vilnius burgher Stepan Syromyatnik and only half redeemed. In the meantime, Syromyatnik had bequeathed the stillmortgaged part of the property to the Magdalene Hospice ${ }^{33}$.

In the 1550s the fortunes of the hospital appear to have declined and the provisor, Valentine of Pilzno, was called to account for the low income of the hospital and the ruination of its buildings and garden $^{34}$. By August 1554 the canons were demanding his dismissal from his post in favour of Jakub Swiderski ${ }^{35}$. In January 1556, Valentinus was on his deathbed and seeking reconciliation with the paupers. He bequeathed to the hospice his house behind the bishop's palace, on condition that the anniversary of his death be remembered and a Mass celebrated in his intention by the hospice chaplain. He set aside annually the sum of half a sexagene of groats for the priest and one and a half score for the feeding of the paupers ${ }^{36}$.

The hospice derived much of its income from the long-term renting out of its buildings (emphiteosis) for three or even ten generations to noblemen and craftsmen (builders, tailors, brewers for between 14 and six sexagena groats (respectively). The downside of this manner of financing the upkeep of the hospice was that not all tenants maintained the almshouse's property in good condition (as Provisor Valentine appears to have found to his cost) and the Chapter Records contain many instances of ruined houses, especially wooden buildings allowed to fall into severe disrepair by tenants ${ }^{37}$. The canons of Vilnius seem to have taken overseeing the hospice

33 Jasas, Pergamentu katalogas No. 420, p. 168, MAVB, F1-122, published in Opisanie rukopisnago otdelenia Vilenskoi Publichnoi Biblioteki, III (Vilnius, 1898), pp. 55-56, No 17.

${ }^{34} \mathrm{ACV}$, t. 3, fos 2, 28. Valentine's career from his Sandomierz origins - LKD, No. 2507, p. 413.

${ }^{35}$ ACV, t. 3, fos 28, 67v. Jakub Swiderski - LKD, No 642, p. 118.

36 See Appendix No 10. The bequest mentioned in the Chapter Records s.a. 1561 - ACV, t. 4, fo. $44 \mathrm{v}$.

${ }^{37}$ See references in Drema, Vilniaus bažnyčios, pp. 569-571, where the source texts are not always transcribed accurately. 
seriously. It is no coincidence that all the major early patrons who left land or tithes to St Job's were careful to remove their donation from subjection to secular jurisdiction and transfer it to ecclesiastical 'jurisdiction and liberty' ${ }^{38}$. Episcopal control was, in theory at least, expected to preserve the independence and proper running of lay donations to the Church.

At a time when the House of SS Job and Mary Magdalene thrived under the management of Martin of Dusniki and Stanisław Dambrowka, fire struck the city in 1530 , leaving two thirds of the town in ashes. It would be logical to assume that the blaze left many people impoverished in its wake. In 1535 the horodniczy of Vilnius Ulrich Hosius asked Grand Duke Sigismund to grant him a charter to build a new bridge across the river for merchants and farmers entering the city. At Transfiguration in 1536, Sigismund issued a charter permitting the official to build a bridge at his own expense, thereafter reimbursing his expenses from a toll of one penny on loads of hay, wood or other produce brought in for sale, five pence on carts drawn by two horses, and a penny on a cow or ox brought to market. From the surplus income, Hosius was to build a hospice for the poor and sick next to the Dominican priory of the Holy Ghost ${ }^{39}$. The hospice, dedicated to the Holy Trinity and known also as the Holy Ghost Hospice (because of its location and the spiritual supervision owed it by the friars-preacher) was to have two entrances; one leading to the Dominican Church, the other leading out onto the street. After the toll income had provided for the construction work, its money was to be directed to food, clothing, medecine and other requisites for the paupers. The friars were obliged to say Mass, hear confessions, and give Holy Communion to the inmates. That the house be run properly it was subjected to supervision by the local bishop. This hospice even more so than its elder sister beside the castle was in the care of the citizens of Vilnius. On 29 January 1546 the city councillor and goldsmith Erasmus Brethner bequeathed his house in St John's Street and an annuity for the upkeep of the paupers (pro pauperibus hospitalis Sancti

${ }^{38}$ See Appendix Nos 2, 3, 4, 5, 6, 12.

39 General background - Maroszek, 'Przytułki-szpitałe', p. 199; Sigismund's charter of 6 Aug. 1536 - MAVB, F1-117, Jasas, Pergamenty katalogas No 402, p. 159; publication - Sobranie drevnikh gramot i aktov gorodov Vil'ny, Kovna, Trok, pravoslavnykh monastyrei, tserkvei i po raznym predmetam, I (Vilnius, 1843), No. 25, pp. 42-48. 
Spiritus Vilnensis) ${ }^{40}$. In 1555 the court sub-treasurer, Stanislovas Zachariuszewicius gave the hospice an annual tribute of corn, peas and barley from his estates at Rostyniane and Przystaniane, while 14 years later the king donated a house on the market square facing Vokiečiu Street with its back to Saviciaus Street ${ }^{41}$.

Saviciaus Street in the 1560s was the site also of property belonging to an Orthodox hospice dedicated to Our Saviour (Spasski), which stood near Užupis by the Annunciation Church. Apparently, it was founded in 1507 by Sigismund the Old, who allowed its elder to import 80 stones of wax into the city without payment of excise. This would make it an earlier foundation than St Job's ${ }^{42}$. In 1582 it owned two buildings and many plots of land. The Orthodox Holy Trinity Church was home to a fraternity which oversaw a hospice. In 1589, Sigismund III issued a charter approving of its services. Both hospices benefited from the generosity of Sigismund Augustus, who around Christmas 1544 made pecuniary offerings to these institutions ${ }^{43}$.

In conclusion, we may say that charitable foundations in Vilnius developed in the 16th century from a background of Catholic piety which grew in strength during the previous hundred years or so. The fraternities based in the parish church of St John and the Franciscan Church of the Assumption of Our Lady developed from a desire to remember and win spiritual and temporal benefits for their members, living and dead. For unknown specific reasons but in the hope of encouraging devotion to the poor of a growing city, girded by walls only since 1502, Canon Martin of Duszniki established the Hospice of St Job (later joined as patron by St Mary Magdalene) on waste ground by the river behind the bishop's palace and beyond the walls

${ }^{40}$ Confirmation of Brether's will by King Sigismund, 31 March 1547 - MAVB F1-143, Jasas, Pergamentu katalogas No 494, p. 195, Sobranie gramot, I, No 43, p. 82-86. Concise biography - E. Laucevičius, B.R. Vitkauskienè, Lietuvos auksakalystè XV-XIX amžius (Vilnius, 2001), p. 192.

${ }^{41}$ Maroszek, 'Przytułki-szpitale', pp. 200-201; MAVB F4-11, donation of Savičiaus house to the hospice aby ubostwo we schpitaliu swietej Throicze, albo swietego Ducha, w Wilnie moglo miecz liepsche ku wychowaniu swym opatrzenie; Jasas, Pergamentu katalogas, No 618, p. 246, 5 Dec. 1569.

${ }^{42}$ Maroszek, 'Przytułki-szpitałe', p. 217, citing a report on Vilnius hospices from 1790 .

${ }^{43}$ Ibid., p. 216 and Lietuvos didžiojo kunigaikščio Žygimanto Augusto dvaro saskaitos (1543-1548), 1 knyga, 1544 XI 15-1546 XI 15, ed. D. Antanavičius, tr. S. Narbutas (Vilnius, 2009). 
of the castle in 1514-1518 with the support of the monarch. At least half of the grandees who witnessed the king-grand duke's charter in Brest Litovsk in December 1518 also endowed the new institution with tithes, supplies of food and land. These people are also known for their support of other ecclesiastical foundations in both Vilnius and parishes of the diocese. The poor house was overseen closely by its neighbours, the canons of Vilnius, and its provisor called to account for his shortcomings. The foundation developed as a typical benefice, consolidating its landholdings and tithe income. One main source of its income derived from property within the city and its inner suburbs. It sought to increase its appeal for support by obtaining an indulgence from the papal legate Zaccharia Ferrari for its newly founded guild, the Fraternity of Charity, whose primary duty was to bury the urban poor, a sign not only of traditional guild piety but also of the growth of the urban population. The model set by Canon Martin's foundation led to the foundation later in the century of more poor houses in the city (primarily the Holy Trinity Hospice founded by a citizen and endowed by members of the city council from 1536, the house founded by the Church of St Peter in the Antakalnis suburb, funded by tolls from the bridge across the Neris at Nemencine, or the Jesuit Archfraternity of Mercy, Mons Pietatis established by Piotr Skarga in 1589 to serve the starving poor unable to find shelter in the existing hospices ${ }^{44}$ ). The existence of Orthodox hospices in Vilnius bears witness, as does the functioning of Orthodox fraternities, to the influence of urban Catholic piety on non-Catholic citizens. The hospices became agents for integrating Vilnius society, providing relief for the poor and providing practical expression of piety, which became landmarks in the sacral topography of the city and instruments for urban development, as in the improvement of apparently hitherto uninhabited marshland beneath the castle, a mark perhaps of the area's change of use from defence of the fortress to permanent settlement.

${ }^{44}$ Maroszek, 'Przytułki-szpitałe', p. 208. 


\section{APPENDIX}

\section{Foundation and endowment documents for the Hospital of SS Job and Mary Magdalene, Vilnius and the earliest diocesan parish hospitals (Zelva, Dolistowo), 1508-1556}

\section{Dec. 1518, Brest Litovsk}

At the Sejm in Brest Litovsk King-Grand Duke Sigismund the Old grants Canon Martin of Duszniki his request for a plot of land on which to build an almshouse. He grants a plot in the castle opposite the residence of the bishop of Vilnius on the other side of the Vilnele River

$$
\text { B - Vilnius, LMAVB RS F43-203, p. } 294
$$

This XVII century paper codex $(30.6$ X $19.7 \mathrm{~cm})$ in its XVIII cent. leather binding is the second Liber Privilegiorum of the Vilnius Cathedral Chapter - see KDKDW T. I, Wstęp, (Kraków 1994), pp. xxxii-xxxiii.

Sigismundus ${ }^{1}$ Dei gratia rex Polonie, Magnus dux Lituanie Russie, Prussie et Samogitie etc dominus et heres. Significamus tenore presentium quibus expedit universis, Quia dum pro parte venerabilis Martini de Dusniki ${ }^{2}$ canonici Vilnensis, rogaremur quatenus ei Vilne aream pro edificando hospitali in quo mendici et egroti, quorum alimenta ad communem eleemosynam pertinerent, conservarentur et habitarent, assignaremus, Nos vero bonum et laudabile eius propositum attendentes, dedimus et assignavimus ei aream in quo huiusmodi hospitale edificaret ex adverso curie episcopalis in castro nostro Vilnensi site, ab altera parte fluminis dicti Vilna supra ipsam ripam existentem ad nos pertinentem pleno iure tam late et longe, que est in suis limitibus circumferentialiter, distincta et limitata, damusque et assignamus ac perpetuo ad dictum hospitale in ipsa edificandum ascribimus, nihil nobis vel successoribus nostris in ea iuris vel proprietatis reservantes; liberam eandem laream/ fore $a b$

${ }^{1}$ Sigismund the Old, Grand Duke of Lithuania and King of Poland, 1506-1548.

${ }^{2}$ Martin of Duszniki (fl. 1512-1527), canon of Vilnius, medical doctor, physician of Sigismund the Old - LKD No. 1272, p. 227-228. 
omnibus oneribus et tributis iuxta iura et immunitates aliorum hospitalium presentibus decernentes. Harum quibus sigillum nostrum est subappensum testimonio literarum.

Datum in Brzescie Lituanico ${ }^{3}$, sabbato ante Sancti Thome apostoli, anno Domini millesimo quingentesimo decimo octavo. Presentibus ibidem reverendis patribus dominis Alberto Vilnensi ${ }^{4}$, Paulo Luceoriensi ${ }^{5}$ episcopis et magnificis, generosis, venerabilibus Nicolao Radwil ${ }^{6}$ palatino Vilnensi magni Ducatus eiusdem nostri Lituanie cancellario, Gregorio Oscikonis ${ }^{7}$ palatino Trocensi, nostro curie marschalco, Ioanne Radwil ${ }^{8}$ huius ducatus nostri marschalco terrestri, Alberto Gastoldi ${ }^{9}$ palatino Polocensi, Ioanne Zabrzezinski ${ }^{10}$ palatino Nowogrodensi, Georgio Ilinicz ${ }^{11}$ marschalco et capitaneo nostro Brzestensi, Nemira ${ }^{12}$ capitaneo Drohiciensi et Melnicensi, Ioanne Philipi ${ }^{13}$ custode Vilnensi et secretario nostro syncere fidelibus devoteque dilectis.

${ }^{3}$ Brest Litovsk, city in Belarus at confluence of Mukhavets and Bug rivers; for 1518 sejm see N.A. Maksimeiko, Seimi litovsko-russkago gosudarstva po Liublinskoi unii $1569 \mathrm{~g}$. (Kharkov, 1892).

${ }^{4}$ Bishop Albert Radvila of Vilnius (fl. 1502-1519, bp of V. 1507-1519), GDL Chancellor Nicholas Radvila and Sofia Mantvydaite’s son - LKD No. 73, p. 29-30; M. Antoniewicz, Protoplaści Książąt Radziwiłtów. Dzieje mitu i meandry historiografii (Warsaw, 2011), pp. 35-37.

${ }^{5}$ Bishop Paul Holszański (Alšèniškis) (fl. 1507-1555) of Lutsk (1507-1536), archdeacon of Vilnius (1519-1536), bp of Vilnius (1536-1555) - LKD No. 1877, pp. 320-322.

${ }^{6}$ Nicholas Radvila, palatine of Vilnius, chancellor of the GDL (ca 1470-1522) Antoniewicz, Protoplaści, pp. 19-31.

${ }^{7}$ Gregory (Stanislawowicz) Oscikowicz (Astikaitis) († 1518), palatine of Trakai and marshall of the grand-ducal court - ibid., pp. 112-113.

8 Jan Mikolajewicz Radziwiłł (Jonas Radvila) (ca 1474-1522) land marshall of the GDL, ibid., pp. 37-40.

${ }^{9}$ Olbracht Gasztold (Albertas Goštautas) (ca 1480-1539), palatine of Novgorodok (1508), Polotsk (1514), Trakai (1519), Vilnius (1522-1539) and chancellor of GDL (1522-1539) - Polski Stownik Biograficzny vol. 7, p. 299.

10 Jan Janowicz Zabrzeziński (Jonas Zaberezinskis) palatine of Novgorodok (1509-1530) - J. Tęgowski, 'Ślub tajemny Jana Janowica Zabrzezińskiego. Garść uwag o powiązaniach rodzinnych elity możnowładczej na Litwie w XV i początkach XVI wieku', Średniowiecze polskie i powszechne, 2 (2002), pp. 246-257.

11 Jerzy Iwanowicz Illinicz (†1527) marshall (1519-1526) and lieutenant of Brest Litovsk (1510-1524).

${ }^{12}$ Mikolaj Niemira Hrymalicz lieutenant of Drohiczyn and Mielnik (1499-1533).

13 Jan Filipowicz (Jonas Filipavičius), (fl. 1496-1524), warden of Vilnius Cathedral and grand-ducal secretary, elected bp of Kiev in 1519 - LKD No. 754, pp. 129-130. 
2.

\section{July 1519}

Nicholas Radvila, palatine of Vilnius and chancellor of the Grand Duchy, donates a tithe in all grains from his estate at Buivydiškes for the paupers in the almshouse of St Job, recently built in Vilnius, removing the tithe from secular jurisdiction to ecclesiastical liberty.

$$
\text { B - Vilnius, LMAVB RS F43-203, p. } 292
$$

In nomine Domini amen. Ad perpetuam rei memoriam. Cum virtus pietatis soli Deo propria magnanimis viris innata inter alias virtutes, apostolo teste ${ }^{14}$, ad omnia valet, hinc est quia nos Nicolaus Nicolai Radziviliowicz ${ }^{15}$ palatinus Vilnensis sibi tranquillam salutem eternam et presentem pys operibus conquirere et suis predecessoribus, sicut vis nature in nobis exigit et sanguinis identitas expostulat succurrere cupientes, decimam omnis grani segetum tam camporum quam hortorum quibuscunque nominibus censitarum de curia nostra Buydziwiszki ${ }^{16}$ nuncupata prop pauperibus in hopsitali sancti Job Vilne noviter constructo ${ }^{17}$ decumbentibus singulis annis dandam, extradendam et solvendam donavimus, tribuimus et concessimus et tenore presentium donamus, tradimus et concedimus perpetue et in evum. Et ut nostra presens donatio decime predicte sic per nos deputate maiori certitudine et firmitudine roboretur eandem decimam de iurisdictione et potestate seculari in iurisdictionem, sortem et libertatem ecclesiasticam transponimus et transferimus ac eidem subycimus, supponimus et incorporamus presentibus perpetuis temporibus valituris. In cuius rei evidens testimonium sigillum nostrum presentibus est subappensum, anno Domini millesimo quingentesimo decimo nono mense iulio.

\section{Aug. 1519, Vilnius}

Gregory, son of the palatine of Trakai, grants a tithe in all grain from his estate at Suderve near Buivydiškès to St Job's Almshouse.

${ }^{14}$ As St Paul tells Timothy (1 Tim. iv:8), godliness is profitable to all things.

${ }^{15}$ See above n. 6.

${ }^{16}$ Buivydiškès - village on n.w. edge of modern city of Vilnius.

17 St Job's Almshouse/Hospital founded by Canon Martin and endowed by Sigismund the Old in 1518. 
B - Vilnius, LMAVB RS F43-203, pp. 290-291

In nomine Domini amen. Ad perpetuam rei memoriam. Cum virtus pietatis soli Deo propria magnanimis viris naturaliter sit indita, que attestante apostolo ad omnia valet, hinc est quod ego Gregorius ${ }^{18}$ palatinidis Trocensis, incisor regie maiestatis tranquillam sibi salutem presentem et eternam pys operibus conquirere suisque predecessoribus sicut vis nature te sanguinis identitas exigit et expostulat, succurrere cupiens, decimam omnis grani segetum omnium tam hortorum quam camporum, quibuscunque vocentur nominibus de curia mea Suderwi ${ }^{19}$ dicta circa Buywidiszki consistem pro pauperibus ad hospitale sancti Job Vilne noviter constructam, degentibus singulis annis dandam, extradendam et solvendam dedi, donavi et ascripsi ac tenore presentium do, dono et ascribo perpetue et in evum. Et ut mea presens huiusmodi donatio decime ampliori firmitate roboretur, prefatam decimam per me $\|$ deputatam de iurisdictione seculari in iurisdictionem, sortem et liberalitatem ecclesiasticam transpono et transfero ac eidem suppono et incorporo perpetuis temporibus duraturam. Datum Vilne feria sexta infra octavas Assumptionis Beatissime Virginis Marie. Anno Domini millesimo quingentesimo decimo nono. In cuius rei maius robur et testimonium sigillum meum presentibus est appensum.

4.

\section{Sept. 1519}

Petras Stanislovaitis Kiška, palatine of Polotsk, grants a tithe of field grains from his estate in the hills next to the lands of St Martin beyond the mill belonging to the palatine of Vilnius near the city to the paupers of St Job's Almshouse.

B - Vilnius, LMAVB RS F43-203, p. 291

In nomine Domini amen. Ad perpetuam rei memoriam. Cum virtus pietatis soli Deo propria magnanimis viris innata inter alias virtutes, apostolo teste, ad omnia valet, hinc est quia nos Petrus Stanislai Kiszka $^{20}$ palatinus Polocensis nobis tranquillam salutem eternam et

18 Gregory son of Palatine Gregory Stanislawowicz Oscikowicz of Trakai, carver of the Grand Duchy - Antoniewicz, Protoplaści, pp. 113-117.

${ }^{19}$ Sudervè village $18.5 \mathrm{~km}$ to n.w. of Vilnius.

${ }^{20}$ Petras Stanislovaitis Kiška, palatine of Polotsk (†1534) - N. Asadauskienè, Kišku gimine LDK XV-XVII a. Genealoginis tyrimas (Vilnius, 2003), pp. 130-141. Asadauskienè places Peter in the Polotsk office only in 1521 (p. 135). Peter was an affine of Jonas Radvila with whom he conflicted. 
presentem pys operibus conquirere et suis predecessoribus, sicut vis nature in nobis exigit et sanguinis identitas expostulat, succurrere cupientes decimam segetum camporum de curia nostra in Montanis sita vicina terris Sancti Martini post molendinum palatini Vilnensis prope civitatem Vilnensem pro pauperibus in hospitali sancti Job noviter Vilne constructo decumbentibus, singulis annis dandam, extragendam et solvendam donavimus, tribuimus et concessimus ac tenore presentium donamus perpetue et in evum. Et ut nostra presens donatio decime predicte sic per nos deputata maiori certitudine et firmitate roboretur, eandem decimam decimam in iurisdictionem ecclesiasticam incorporamus perpetuis temporibus valituram. In cuius rei evidens testimonium sigillum nostrum presentibus est subappensum. Anno Domini millesimo quingenstesimo decimo nono secunda mensis septembris.

\section{5.}

\section{Jan. 1520, Vilnius}

Paulis Narušaitis, the king's secretary, grants annually four barrels of wheat and a pig from his hereditary estate at Ašmena for the paupers of St Job's.

B - Vilnius, LMAVB RS F43-203, p. 293

In nomine Domini amen. Ad perpetuam rei memoriam. Cum inter ceteras virtutes magnanimorum virorum altius statum dignificat clementia, que Deo propria mortalibus tamen, apostolico testimonio, ad omnia utilis existit, quam et Salvator noster consiliorum et salubrium preceptorum expositor clementissimus habendam nos admonuit. Pro modulo itaque ego Paulus Naruszowicz ${ }^{21}$ secretarius regie maiestatis etc propitiationis Salvatoris nostri experti eiusmodi admonita sequi cupientes salutemque eternam et presentem nobis et amicis nostris conquirere predecessoribusque nostris vita functis succurrere, sicut vis nature exigit et sanguinis identitas expostulat, satagentes singulis annis perpetuis quatuor tunnas siliginis et porcum de curia hereditaria nostra in Oszmana ${ }^{22}$ constituta ad hospitale Sancti Job Vilne noviter constructum pro pauperibus degentibus danda, extradenda et solvenda dedimus, donavimus et contribuimus ac tenore presentium damus,

${ }^{21}$ Paulius Narušaitis (Pawel Naruszewicz), secretary to the king.

${ }^{22}$ Ašmena (Oszmiany, Ashmiany), town $50 \mathrm{~km}$ s.e. of Vilnius, former grandducal administrative centre. 
donamus, conferimus perpetue. Ut autem prefata nostra donatio maiori certitudine et firmitate roboretur, eandem donationem sic in modum elemosyne sempiterne per nos deputatam de iurisdictione et poteste seculari in iurisdictionem, sortem et libertatem ecclesiasticam transponimus et transferimus ac eidem subycimus, supponimus et incorporamus perpetuis temporibus duraturam. In cuius rei evidens testimonium sigillum nostrum presentibus est subappensum. Actum et datum IVilne/ vigesima tertia January anno Domini millesimo quingentesimo vigesimo.

6.

\section{April 1522, Dworzyscze}

Jurgis Iliničius, lord lieutenant of Brest and marshall of the Grand Duchy, makes an annual donation of ten barrels of wheat and ten shanks of pork from his estate at Dvorzycze (Lyda District).

B - Vilnius, LMAVB RS F43-203, pp. 292-293

In nomine Domini amen. Ad perpetuam rei memoriam. Cum inter ceteras virtutes magnanimorum virorum altius statum dignificat clementia, que Deo propria mortalibus tamen, apostolico testimonio, ad omnia utilis existit, quam et Salvator \noster/ consiliorum et salubrium preceptorum expositor clementissimus habendam nos admonuit. Pro modulo itaque nos Georgius Ilinicz ${ }^{23}$ capitaneus Brestensis et marschalcus Magni Ducatus Lituanie, propitiationis Salvatoris nostri experi eiusmodi admonita sequi cupientes salutemque eternam et presentem nobis et amicis nostris conquirere predecessoribusque nostris vita functis succurrere, sicut vis nature exigit et sanguinis identitas expostulat, satagentes singulis annis perpetuis decem tunnas siliginis et decem pernas lardi de $\|$ curia nostra Dworzycze ${ }^{24}$ nuncupata in districtu Lidensi consistenti ad hospitale sancti Job Vilne noviter constructum pro pauperibus degentibus danda, extradenda et solvenda dedimus, donavimus et contribuimus ac tenore presentium damus, donamus, conferimus perpetue. Ut autem prefata nostra donatio maiori certitudine et firmitate roboretur, eandem donationem sic in modum elemosyne sempiterne per nos deputatam de iurisdictione et poteste seculari in iurisdictionem, sortem et libertatem ecclesiasticam

${ }^{23}$ See n. 11.

${ }^{24}$ Dvoryshcha, small town to n.e. of Lida in Belarus. 
transponimus et transferimus ac eidem subycimus, supponimus et incorporamus perpetuis temporibus duraturam. In cuius rei evidens testimonium sigillum nostrum presentibus est subappensum. Datum in Dworzyscze die xx aprilis anno Domini MDXXII.

\section{7.}

\section{Jan. 1522, Vilnius}

During a chapter meeting held on Epiphany Day 1522 in St Stanislaw's Cathedral the bishop-elect of Vilnius, John of the Lithuanian Dukes, notes how his predecessor Albert Radvila died having made an endowment of marshy land to the paupers of St Job and St Mary Magdalene's almshouse, but without issuing a document to that effect. John decides to issue a written endowment of the deserted, marshy, uncultivated and uninhabited plot, which lies between the house of Lord Klocko and the garden of Canon Albinus.

$$
\text { B - Vilnius, LMAVB RS F43-203, p. } 295 \text { (fo 149) }
$$

In nomine Domini amen. Ad perpetuam rei memoriam. Nos Ioannes ${ }^{25}$ ex ducibus Lituanie Dei gratia electus et confirmatus Vilnensis significamus tenore presentium universis et singulis quibus expedit harum notitiam habituris, Qualiter relatum est nobis in capitulo per nonnullos prelatos et canonicos ecclesie nostre bone recordationis reverendissimum in Christo patrem Dominum Albertum Radiwil ${ }^{26}$ olim episcopum Vilnensem predecessorem nostrum perpetua et irrevocabili donatione donavisse et concessisse hospitali sanctorum Job et Marie Magdalene Vilne sub castro sito pro sustentatione pauperum in eo degentium terram desertam alias locum paludinosum nunquam inhabitatum neque cultum suum epsicopalem domui domini Klocko $a b$ una et horto domini doctoris Albini ${ }^{27}$ ab alteri confinantem partibus, possessione reali et actuali subsecuta nihil pro se et suis successoribus in eadem reservantes. Et quoniam item predecessor noster, sicut Altissimo placuit, ab hac luce migravit, literis huiusmodi donationis non confectis, idcirco nobis \fuit/ pro parte pauperum

${ }^{25}$ John of the Lithuanian Dukes (1499-1538), bastard son of Sigismund the Old, bishop of Vilnius - elected 1519, resigned 1536 - LKD No. 796, pp. 135-136.

${ }^{26}$ Bishop Albert Radvila - see n. 4.

${ }^{27}$ Canon Jan Albin (Jonas Albinas) of Vilnius (fl. 1510-1525), canon lawyer, Visitor of Dioceses of Žemaitija (1518) and Vilnius (1522) - LKD No. 792, pp. 134-135. 
hospitalis predicti humiliter supplicatum, quatenus huiusmodi donationem terre deserte pio loco per presecessorem nostrum sicut prefertur factam, in robore aut denuo donare literasque desuper necessarias de consensu nostri capituli sibi concedere dignaremur. Nos igitur attendentes petitionem huiusmodi fore iustam et rationi consonam quodque cura pastoralis oficii nobis commissi nos permovet ut solicitam et indefessam in Domino faciamus operam ne pauperes varys languoribus correpti, inedia aut frigore, sine paterna provisione, velut cetera animantia intereant. Ea propter huiusmodi petitione benigne annuentes donationem terre paludinose et inhabitate pauperibus hospitalis sanctorum Job et Marie Magdalene ${ }^{28}$ per predecessorem nostrum factam in toto ratficamus, approbamus, confirmamus et denuo concedimus, damus, donamus ac de consensu nostri capituli ad id ibidem expresse consentientis ascribimus perpetuo et in evum et robur perpetue firmitatis apponimus, nihil iuris et dominy pro nobis et successoribus nostris sibi in eadem reservando. In cuius rei testimonium presentes literas fieri sigillique nostri iussimus et fecimus aubappensione communiri. Actum et datum Vilne apud Sanctum Stanislaum nobis inibi cum prelatis et canonicis pro ecclesie negotys et capitulo celebrando capitulariter in loco capituli congregatis $^{29}$ ipso die festo Trium Regum sub anno a Nativitate Domini millesimo quingentesimo vigesimo secundo.

\section{8.}

\section{June 1526, Vilnius}

Bishop John of Vilnius confirms charters presented by the warden of St Job and St Mary Magdalene's almshouse in Vilnius, Dr Martin of Duszniki, concerning tithes from three estates belonging to the parish Church of Kernave, then in possession of Canon Erazm Eustachy

B - Vilnius, LMAVB RS F43-203, p. 289-290

In nomine Domini Amen. Ad perpetuam rei memoriam. Nos Iohannes ex Ducibus Lituanie Dei gratia electus et confirmatus Vilnensis significamus tenore presentium universis et singulis, quibus expedit, harum notitiam habituris, Quia in nostri presentia personaliter constitutus venerabilis vir Dominus Martinus de Dusz-

28 The almshouse now bears an additional dedication to St Mary Magdalene.

${ }^{29}$ A chapter meeting held in the cathedral on Epiphany Day 1522; records of this do not survive. 
niki artium et medecine doctor, canonicus Vilnensis et pauperum hospitalis Sanctorum Job et Marie Magdalene in civitate Vilnensi provisor quasdam literas donationis decimarum manipularium de curiis Chrczonowe et apud Venceslaum et Georgium Harkowiczy ac apud Bogdziewicy ecclesie parochiali in Kiernow ${ }^{30}$ nostre diecesis Vilnensis pertinentes per honorabilem Dominum Erasmum \| Eustachium de Cracovia ${ }^{31}$ eiusdem ecclesie in Kiernowo rectorem cum certis oneribus in eis expressis facte, exhibuit. Quam quidem donationem decimarum per nos admitti eique robur perpetue firmitatis apponi instanter postulavit. Nos attendentes, quod huiusmodi donatio nulli prejudicium ingerere potest, ipsam tamquam canonice factam de consensu nostri capituli, qui omnino in aliqua sessione generali requirendus et obtinendus erit in toto admittimus necnon ratificamus, approbamus et confirmamus roburque perpetue firmitatis autoritate nostra ordinaria apponimus. Decernentes, quod huiusmodi decima ex nunc in posterum de curiolis predictis pauperibus hospitalis predicti ex vi donationis per nos approbata singulis annis perpetuis futuris, remota quavis cavillatione, persolvantur.

In cuius rei testimonium presentes literas fieri sigillique iussimus nostri subappensione communiri. Actum et Datum Vilne in curia nostra episcopali die martis quinta mensis Iuny, anno Domini millesimo quingentesimo vigesimo sexto

9.

\section{July 1536, Vilnius}

Canon Stanislaw Dambrowka of Vilnius, parish priest of Dolistovo and Miedzybor, warden of St Mary Magdalene's Almshouse, exchanges with the noble Marcus Lepkowski and his wife Elizabeth land lying between the houses of the Vilnius burghers Nicholas Szastok and Peter for land beyond the city walls between the plots of the said Peter and the noble Laurencius Szoszynski.

B. Vilnius, LMAVB RS, F43-203 (Lib. II) fo. 146, p. 289

In nomine Domini Amen. Ad perpetuam rei memoriam. Tam presentibus quam futuris notum sit etc. Quod ego Stanislaus Da-

${ }^{30}$ Kernavè, small town $18 \mathrm{~km}$ s.w. of Širvintos, $35 \mathrm{~km}$ n.w. of Vilnius.

${ }^{31}$ Erazm Eustachy of Cracow (fl. 1512-1545/1546), canon of Vilnius, parish priest of Kernavė, Kaunas and Pasvalys, a particularly rapacious cleric - LKD No. 421, pp. 86-87. 
browka $^{32}$ magister artium liberalium, canonicus Vilnensis necnon plebanus in Dolistow ${ }^{33}$ et Miedzyborze ${ }^{34}$ et procurator hospitalis protunc Sancte Marie Magdalene, non coactus sed spontanea bona voluntate mutavimus hortos cum nobili Domino Marco Lepkowski necnon ipsius uxore Elizabeth, qui hortus iacet inter domos Domini Nicolai Szostak et Petri civis Vilnensis et ego etiam Marcus Lepkowski dedi meum proprium hortum venerabili viro Domino canonico penes wal extra muros Vilnenses, qui hortus iacet penes domum nobilis Domini Laurenty Szoszynski et predicti Petri ex alia parte perpetue et in evum possidere, tenere, vendere, condonare ad suum libitum vertere.

In cuius maius testimonium sigilla nostra sunt subimpressa. Datum Vilne die Mercury vigesima tercia mensis Iuly sub anno Domini millesimo quingentesimo trigesimo sexto, presentibus generosis, nobilibus et famatis, videlicet Laurentio Hanczewicz vexilifero Suderwiensi ${ }^{35}$, Mathia Modzelewski apotecario, Stanislao Bartoltowicz et Sebastiano hospitalis factore et alys fide dignis.

10.

\section{Jan. 1556, Vilnius}

Valentine of Pilzno, canon of Vilnius, understanding the power of the prayers of the poor, bequeaths his house behind the Bishop's Curia to the Almshouse of St Mary Magdalene under the following conditions: Canon John Sciurus is to keep the house for his lifetime, provided that each year he gives the almshouse chaplain 30 groats to feed the paupers on the anniversary of Valentine's death; if John refuses to do so, the house falls under the control of the Vilnius Chapter with the proviso that each year the almshouse chaplain receives 30 groats for a memorial Mass, with the remainder of the income from the house going to the paupers and the repair of the building.

${ }^{32}$ Stanislaw Dąbrowka (fl. 1503-1546), canon of Vilnius, parish priest of Dolistovo and Międzyborz - LKD No. 2195, pp. 363-364.

${ }^{33}$ Dolistów - large village in Podlasie on River Biebrza, to n.e. of Goniądz.

${ }^{34}$ Międzyborz - now Niedzbórz, Diocese of Płock in Mazovia, village in the Ciechanów District.

${ }^{35}$ Laurence Hanczewicz, standard-bearer of Sudervè. 
B - Vilnius, LMAVB RS F43-203, pp. 296-297

Advenas nos esse in hoc mundo et peregrinos sacra testantur eloquia ${ }^{36}$, peregrinorum vero est cogitare ut aliquando securi perveniant ad patriam, que cui dulcis est, amara est ei omnis peregrinatio. Cum autem nostra vera patria regnum sit celeste, ad illud ut peregrinamus, adnitendum est omnibus. Quocirca ego Magister Valentimus Pilznensis ${ }^{37}$, canonicus Vilnensis, pressus magna egritudine et mortem per quam ad vitam propinquam mihi adesse cernens, et non ignorans viam celi, esse pauperes per quam venitur ad patriam, proposui in anima mea pauperes mihi conciliare ut per eorum orationes, corpore solutis, ad illam patriam eternam possem pervenire. Itaque licet sim eger corpore, valeam tamen mente, nullo errore seductus sed consulto ac vere premeditatus riteque saluti anime mee consulere volens, domum meam propriam retro curiam episcopalem sitam post obitum meum do atque lego perpetue ad hospitale sancte Marie Magdalene in hunc qui sequitur modum. Ut scilicet Magister Joannes Sicurus ${ }^{38}$ canonicus Vilnensis et parochus antocolnensis eam ad vitam suam (si voluerit) possideat et gubernet ipsamque restauret ac reformet et quoad vixerit quolibet anno diem obitus mei commemorando, capellano hospitalis pro tempore existenti mediam det sexagenam ut vigillas cum messa anniversaria cantando eodem die celebret et unam cum media sexagenam tradat pro victu pauperorum. Quod si ipse paratam domum aut habere noluerit aut per aliquot tempus possessam libere dimittere voluerit, aur post mortem suam eam reliquerit vel eam restaurare negligat, extunc eandem venerabili capitulo vilnensi in utilitate hospitalis gubernandam et cui illud voluerit locandam committo, eadem conditione ut anniversarius dies quotannis observetur et triginta grossi pro exequiis capellano dentur, reliquum vero quantumcunque fuerit, in usum pauperum et si opus fuerit, aliquid ad reformationem parate domus conferatur. In cuius rei testimonium sigillum meum his litteris est annexum, quas etiam manus propria subscriptione munivi. Presentibus notariis

${ }^{36} 1$ Peter ii:11.

${ }^{37}$ Valentine of Pilzno (Sandomierz Land) (fl. 1535-1556), canon of Vilnius, warden of St Mary Magdalene's Almshouse, 1550-56, disciplined for poor administration of the house - LKD No. 2507, p. 413.

38 Jonas Sciurus (Latin for squirrel, or wiewiórka in Polish) of Voveres (Wawiorka) (fl. 1524-1563), canon of Vilnius, parish priest of Antakalnis - LKD No. 831, p. 145. 
publicis videlicet honorando domino Ioanne Strembosio parocho ${ }^{39}$ Mostensi etc, Stanislao a Wagrow ${ }^{40}$ causarum $\|$ consistorii vilnensis procuratore testibus ad promissa vocatis et rogatis. Actum et datum Vilne in predicta domo mea die saturni vigesima quinta mensis Januarii Anno Domini millesimo quingentesimo quinquagesimo sexto.

Ego Magister Valentinus canonicus vilnensis manu propria subscripsi. Et me Gregorio Cervino ${ }^{41}$ Posnaniensi notario publico, qui huiusmodi literarum confectioni, ordinationi et subscriptioni una cum prenominatis testibus presens interfui eaque omnia et singula sic fieri vidi et audivi. Ideo me presentibus subscripsi in fidem et testimonium per dictum Valentinum magistrum rogatis et requisitis. Idem qui supra manu propria.

11.

\section{April 1508, Vilnius}

Ona Iliničiuviene confirms her emoluments for Zel'va parish church, which was founded by her forebears and dedicated to the Holy Trinity. She grants men and land at Studeniki; tithes from her manors at Zel'va Maior, Kremyanitsa, Shilovichi and Svislach'; an inn for reconstruction at Zel'va; 120 groats annually from the Zel'va taverns; 240 groats on the feast of St James the Great; honey; wax for candles on the high altar and by the tomb of her parents, wax for the Paschal candle; tribute from Shilovichi manor to support the school and scholars at Zel'va; grain from Shilovichi for the paupers at the Almshouse run by the parish priest in Zel'va (if it should not cease to function); in return Masses are to be offered in perpetuiy on Tuesdays in honour of St Anne and on Saturdays in celebration of the Assumption.

B - Kraków, Biblioteka XX. Czartoryskich, Cz 1777 IV, pp. 236-238

[fos 78v-79v] Vilnius Chapter Archive, Diocesan Privilegia seu fundaciones ecclesiarum dioecesis Vilnensis $(31 \times 20 \mathrm{~cm})$, in many documents close to Liber Magnus (Vilnius, LMAVB RS, F43-204), fos $92 \mathrm{v}-94 \mathrm{r}-K D K D W$, Wstęp, pp. xxxvii-xxxviii.

${ }^{39}$ Jonas Strembošas of Jablonica (Sandomierz Land) (fl. 1524-1562), parish priest of Wawiorka - LKD No. 827, pp. 141-142.

${ }^{40}$ Stanislovas Vengrovietis (fl. 1534-1560), notary apostolic and procurator of Vilnius Consistory Court - LKD No. 2261, pp. 373-374.

${ }^{41}$ Grigalius Červa (fl. 1541-1571), canon of Medininkai (1561-1571), notary apostolic - LKD No. 501, pp. 98-99. 
In nomine Domini amen. Anno a nativitate Eiusdem millesimo quingentesimo octavo, indictione undecima, pontificatus sanctissimi in Christo patris et domini nostri domini Julii divina providentia pape secundi, anno eius quinto, die vero octava Aprilis hora terciarum vel quasi in curia magnifice domine Anne Hylyniczowa ${ }^{42}$ penes fluvium Vylna vulgariter nuncupatum sita. In jure notarii publici et testium infrascriptorum personaliter prefata magnifica domina Anna Hylyniczowa volens de donis perpetuis pro peccatis suis et anime ac animarum antecessorum suorum et ipsorum providere saluti, disponere et ordinare laudemque Dei Omnipotentis ampliare et, ut tenetur, augmentare totis viribus, proventibus et oblationibus, ut quidquid seminaret in terris illa in celis inveniret congregata, pro terrenis et transituris premia consequatur celestia eterna. Ut autem ecclesia parrochialis in Zelwye ${ }^{43}$ per suos antecessores fundata et dotata in officiis divinis et orationibus defectum et detrimentum non patiatur, sed eo abundantius laus Omnipotenti Deo, Sancte Trinitati et ipsius ecclesie patronorum persolvatur Glorioseque Genetrici et sanctis omnibus honor temporibus debitis impertratur, exhibeatur et persolvatur.

Proinde de omnibus melioribus modo via, iure, causa, stylo etforma, quomodo melius et utilius potuit et debuit ad eandem ecclesiam in Zelwa sic, ut premittitur, per antecessores suos fundatam et dotatam, qui divina inspiratione et devotionis fervore maturo consilio intra se prehabito, terram et hereditatem vulgariter in districtu Studzyenyecz ${ }^{44}$ iacentem una et tredecem homines et terram ipsorum sufficientem, Primus homo Mykolay, secundus Woythek frater suus, tertius Kalutha frater eorum, quartus Iwanyecz Mostulycz, quintus Hrynhecz frater suus, sextus jacobus, septimus Szamochwa frater suus, octavus Daszko filius Szamochwal, nonus Vyeryha, decimus Protasz frater eius, undecimus Martinus, duodecimus Carp, tredecimus Joannes Chodor frater Martini Carp et cum eorum uxoribus et pueris, servitute, dationibus, censibus, tributis omnibusque iuribus et pertinentys, agris, pratis, campis cultis et incultis, sicut sola habuit, tenbuit et possedit, nihil iuris vel dominii pro se vel successoribus suis legitimis in eisdem hominibus reservando, dans eidem plebano et successoribus eiusdem ecclesie in prefatis hominibus omne ius et

${ }^{42}$ Ona Iliničiuvienė (Anna), wife of Jerzy Iwanowicz Illinicz - see n. 11.

${ }^{43}$ Zel'va, small town in western Belarus on banks of Zel'vyanka river, $132 \mathrm{~km}$ from Grodno.

${ }^{44}$ Studeniki, town s.e. of Svislach', Grodno District. 
voluntatem regendi et defendendi ac gubernandi tanquam proprios ecclesie prefate subiectos. Item ad eandem ecclesiam et successoribus perpetuis do, ascribo et incorporo decimas omnium curiarum et curiolarum patrie mee legittime de Zelwye majori, Krzemienycz ${ }^{45}$, Szydlowicze ${ }^{46}$ et de Szwysszlecz ${ }^{47}$. Item decimam omnis grani tam de agris quam de hortis, equorum, iumentum, porcorum ordinamus pecudum et pecorum, gallorum, ancarum et generaliter omnium nascendorum ad eandem ecclesiam et eius successoribus, duntaxat de curia Zelwye, de aliis vero curiis superius expressis decimam avene, tritici, siliginis, hordei, ciceris, mileorum tantummodo habebit et habebunt. Item cassavit et cassat decimam, que ex antiquo dabatur, videlicet quadraginta capete siliginis, cuius in locum decimam de dictis curiis ascripsit et donavit. Item tabernam liberam ibidem in Zelwa tenendum, habendum et de novo edificandum cum omnibus proventibus et constitutionibus et iuribus eorum. Et si hoc successores mei tenere et admittere recusaverint, extunc omni anno predicti successores eidem plebano et successoribus de tabernis in Zelwye prefata duas sexagenas monete currentis in Ducatu Lituanie perpetuis temporibus singulis annis dare et solvere tenebuntur et astricti erunt. Item ad eandem ecclesiam et ipsius successoribus do, ascribo, et succesores meos dare et solvere volo, etiam temporibus perpetuis singulis annis quatuor sexagenas monete Lithuanicalis pro Festo Sancti Jacobi ${ }^{48}$ apostoli de prefatis tabernis in Zelwya. Item ad eandem ecclesiam do, ascribo et successoribus prefatis Lukno Nabatowskie mellis crudi ex curia Szydlowicze. Item duos lapides cere pro luminaribus ad altare maius et ad sepulchrum ubi corpora parentum suorum requiescunt et pro candela magna ad festum Pasche facienda perpetuis et singulis annis de prefata Zelwye et successores sui dare et solvere tenebuntur et erunt obligati. Item pustewnik incipiendo a fovea, qua Zelwye circumdatur usque ad fluvium eidem plebano et suis successoribus perpetuiter ascripsit et donavit. Item pro loco et terra plebani, ubi Stanislaum altaristam locavit, dedit et dat commutationem equalem, secundam terram plebani in Szyenkowskie Szianoszaczy perpetuo tenendum et habendum. Item ad eandem ecclesiam de curia Szydlowycze propter scolares et scolam, quos plebanus nutire et providere propterea tenebitur et successores

\footnotetext{
${ }^{45}$ Kremyanitsa, small town 10 k. n.w. of Zel'va.

${ }^{46}$ Shilovichi, town in Belarus $20 \mathrm{~km}$ n.w. Volkovysk.

${ }^{47}$ Svislach', administrative town in Belarus, s.w. Volkovysk.

${ }^{48}$ Feast of St James the Greater - 25 July.
} 
tres tunnas farine, siliginis, et unam tunnam pisi et duos porcos perpetuis temporibus dedit et ascripsit successoresque sui dare et solvere tenebunbtur. Item ad hospitale de curia Swislecz, quod est in Zelwya, si duraverit et non dsesertabitur de gratia spirituali duas tunnas siliginis, farine et quartam partem tunne pisi et unum porcum pro pauperibus singulis annis et temporibus perpetuis dedit, donavit atque ascripsit et per suos successores dari et solvi voluit et promisit. Item hospitale plebano et eius successoribus commisit gubernandum, regendum et providendum. Plebanus vero modernus eiusdem ecclesie et eius successores legitimi propter donata, inscripta et dotata perpetuis annis et temporibus singulis hebdomadis et diebus in eadem ecclesia duas missas, unam videlicet die martis sive feria tertia de Sancta Anna, matre Marie, et secundam sabbativis de Assumptione Virginis gloriose cantare tenebitur, tenebuntur et erunt astricti et eorum quilibet erit astrictus et obligatus. Promisit nihilominus prefata magnifica domina Anna mihi notario publico infrascripto solenniter stipulando et recipiendo omnia et singula in presenti privilegio sive publico instrumento contenta et conscripta atque donata et dotata gratum, ratum atque firmum perpetuo et irrevocabiliter teneri per se et succesores suos pariter et observare. Super quibus omnibus et singulis premissis prefata domina a me notario publico infrascripto petyt sibi fieri et confici et premissis presens publicum instrumentum.

Acta fuerunt hec anno, indictione, pontificatu, die, mense, hora et loco quibus supra, presentibus ibidem magnifico Domino Georgio Hynycz $^{49}$, discretis Joanne plebano in Zelwye ${ }^{50}$ et Stanislao ipsius plebani fratre germano, domino Luca Noskowsky in medicinis doctore, Nicolao Thupyk de Horna et Paulo Daszkowicz. Et ego Jeremias Matthie de Czarnkow, clericus Posnanensis diecesis apostolica et imperiali autoritatibus notarius publicus et facti huiusmodi scriba, quia predictis privilegii fundationi huiusmodi decimarum, pecuniarum et aliorum proventuum ad secundam supradictam donationi, incorporationi et ascriptioni, missarum obligationi et deputationi aliisque omnibus et singulis, dum si agerentur et fierent una cum prenominatis testibus presens interfui omniaque et singula sic fieri vidi et audivi et in notam scripsi et qua hoc presens privilegium sive instrumentum publicum manu mea propria scriptum extraxi et publicavi signoque et nomine una cum prenominate domine Anne

${ }^{49}$ See n. 11.

${ }^{50} \mathrm{John}$, parish priest in Zel'va - LKD No. 788, p. 134, brother of Stanislaw. 
sigilli appensione meis solitis et consuetis communivi et consignavi in fidem et testimonium omnium et singulorum premissorum rogatus et requisitus. ${ }^{51}$

\section{2.}

\section{March 1530, Vilnius [6 Feb. 1530, Vilnius]}

Bishop John of Vilnius confirms the foundation of St Stanislaw's Hospice in Dolistovo Parish Church by the local parish priest and canon of Vilnius Stanislaw Dambrowka. Stanislaw donates a tithe of all grains from Karp's ploughland at Zabiele and Brzozowo (which the priest had sold to Karp). The hospice advowson remains in the gift of the priest and his successors as rector of Dolistowo.

$$
\text { B - Vilnius, LMAVB RS F43, b. 204, fo. 174-175 }
$$

Ad perpetuam rei memoriam. Dignum est atque honestum ea, que per pias mentes in honorem Omnipotentis Dei pietatis devotionisque gratia offeruntur, iusto perpetuitatis privilegio communiri. Proinde nos Joannes ex Ducibus Lituanie Dei gratia electus, confirmatus Vilnensis animadvertentes venerabilis fratris nostri Domini Stanislai Dabrowka ${ }^{52}$ canonici vilnensis et plebani in Dolistowo diocesis nostre syncerum affectum, quam in augendo cultu divino satis vigilem ac studiosum presefertur, noluimus sibi auctoritatis nostre accessionem ad illius animi institutm negare, imo potius literas privilegy seu fundati super prepositure capelle hospitialis in prefata Dolistowo sub titulo Sancti Stanislai pontificis || et martyris per ipsum Dominum Stanislaum canonicum noviter fundata contentaque ac specificata in eisdem sue petitioni ut pote juste racioni consone satisfaciendo auctoritate nostra ordinaria confirmandas et approbandas immunitatique et libertati ecclesie ascribendas censuimus. Quarum quidem literarum tenor in hec verba sequitur:

In nomine Domini amen. Universis et singulis presentibus et futuris harum notitiam habituris. Ego Magister Stanislaus Dambrowka

${ }^{51}$ On Fos $77 \mathrm{v}-78 \mathrm{v}$ we read that on the same day in the same place Anna made an emolument for the Altar of Our Lady, All Saints, Exaltation of the Holy Cross, the Holy Trinity, the Assumption. It stood on the left side of the church at Zel'va and was to receive men, land, wood and honey; a stone of wax each 27 Sept. from Shilovichi and 120 groats a year from the Zel'va taverns in return for three Masses a week (For the Dead, on Wednesdays; The Five Wounds, on Fridays; The Seven Joys of Our Lady, on Saturdays).

52 Stanislovas Dąbrowka - see n. 32. 
canonicus Vilnensis et ecclesie parrochialis in Dolistowo eiusdem Vilnensis diocesis rector in perpetuam rei memoriam deduco. Quod cupiens terrena in celestia et transitoria in eterna felici commercio commutare, preposituram in capella Sancti Stanislai in Hospitali Dolistowo constructam in titulum beneficy secularis perpetui fundo pro dote et fundo decimam manipularem omnis grani post araturam Nobilis Karp et eius successorum de Zabiele et Brzozowo ${ }^{53}$ do et assigno, quam quidem decimam ego in eodem Karp iure iusto mihi lucratus sum et in usum perpetuum pro arbitrio meo convertendum vendicavi. Cuius quidem prepositure iuris patronatus et presentandi mihi dum superstes ero et ecclesie parrochialis in Dolistowo rectoribus pro tempore existentibus, do et reservo et quia qui fruitur commodo, dignum est eum sentire onus prefatum, prepositum eiusdem capelle pro tempore existentem obligo et astringo ac eius successores perpetuis futuris temporibus obligatos esse volo ut omni feria sexta missam de Sancto Stanislao, ac quatuor temporibus autumnalibus requiem pro defunctis semel in anno in eadem capella legat et compleat, ac ad ecclesiam prefatam in Dolistowo parrochialem ad omnes processiones tam solennes quam domicales suppeliciatus more aliarum ecclesiarum interesse tenebitur, presentibus perpetuis temporibus duraturum. Ad quam quidem preposituram taliter per me fundatam et dotatam vobis reverendo in Christo patri et domino Domino Joanni ex Ducibus Lituanie Dei gratia electo confirmato Vilnensi vel vestre reverendissime paternitatis in spiritualibus vicario ad id potestatem habenti honorabilem Malcherum ${ }^{54}$ de Brok, presbyterum diocesis Plocensis presento, supplicans dignetur ad presentationem hanc meam ad preposituram prefatam huiusmodi nove mee fundacionis vacantem instituere administrationem spiritualium et regimen temporalium in ea committendo, prout id ad vestre paternitatis officium dignoscitur pertinere. Actum et datum Vilne in edibus solite mee residentie, die sexta Februarii anno Domini millesimo quingentesimo trigesimo sub sigilli mei appensione.

Nos itaque Joannes ex Ducibus Lituanue Dei gratia episcopus Vilnensis prefatus preposituram Hospitalis in capella Sancti Stanislai prefata, ut prefertur, noviter fundatam in perpetuum secularis

${ }^{53}$ Fo. 127: According to a 1519 dispute between Mordasz and Stanislaw; Mordasz claims to have agreed with previous parish priest to pay 30 groats rather than the tithes from Brzozowo and Zabiele and had in fact been paying 40 gr. The judge, Nicholas Radziwill, chancellor, found in favour of Stanislaw.

${ }^{54}$ Merkelis Brokiškis, Dobrynevo Almshouse warden - LKD No. 1357, p. 242. 
beneficy titulum auctoritate nostra ordinaria erigeri duximus atque presentibus literis nostris erigimus fundumque ipsius prepositure et universas decimas in preinsertis literis expressas per prepositos dicte capelle pro tempore existentes utifruenda pacificeque et quiete possidendum $\|$ immunitati ac libertati ecclesiastice ascribimus et incorporamus onerando conscientias possessorum dicte prepositure ne officia et onera in preinsertis literis specificata negigerent. Cuius prepositure iurispatronatus et presentandi moderno domino Stanislao Dambrowka in Dolistowo plebano et pro tempore existentibus reservamus honorabilemque Malcherum de Brok actu prasbyterum diocesis Vilnensis ad preposituram prefatam ad presentationem ipsius Domini Stanislai Dambrowka plebani instituimusque et investimus administrationem spiritualium et regimen temporalium in eadem committendo. Ut autem dicte prepositure capella in suis structuris, edificiis, ornamentis commodius provideri possit de speciali gratia nostra universis et singulis sexus utriusque Christi fidelibus in utroque Sancti Stanislai ${ }^{55}$ festo dictam capellam visitantibus et manus adiutrices porrigentibus, contritis et confessis quadraginta dies indulgentiarum concedimus. Harum quibus testimonio literarum sigillum nostrum presentibus est subappensum.

Actum et datum Vilne, anno Domini millesimo quingenstesimo trigesimo, die septimo mensis marty, presentibus Reverendo et honorabilibus ac discretis viris Dominis Joanne de Domanow ${ }^{56}$ precepto vilnensi, cancellario nostro, Mathia Berthran ${ }^{57}$ in Miedniki, Joanne Strzamboch $^{58}$ in Maiori Wawerka plebanis ac aliis quam plurimis circa premissa testibus fidedignis.

\section{Author Details}

Professor S.C. Rowell is senior research associate at the Department of History of the Grand Duchy of Lithuania, Lithuanian Institute of History. His main scholarly interests are late medieval history of the Grand Duchy of Lithuania and Kingdom of Poland.

Address: Lithuanian Institute of History, Kražių 5, Vilnius LT-01108

${ }^{55}$ In Poland and Lithuania St Stanislaw has two feasts, namely 8 May, the day of his death; and 27 Sept., the date of the translation of his relics. The Church Universal celebrates his feast today on the anniversary of his death, April 11.

${ }^{56}$ Jonas Domanovskis (fl. 1524-1563), canon of Vilnius, from Domanova in Bielsk - LKD No. 830, pp. 142-145.

${ }^{57}$ Motiejus Bertrandas (fl. 1520-1530), priest of Płock and Vilnius dioceses, notary public, parish priest in Rudamina (1524-1526) and Medininkai (1526-1530)LKD No. 1725, p. 298.

${ }^{58}$ See above n. 39. 
LABDARINGOS VEIKLOS VAIDMUO FORMUOJANT VILNIAUS MIESTO VISUOMENE XIV A.-XVI A. VIDURYJE

Santrauka

\section{S.C. ROWELL}

Autorius peržiūri labdaringos veiklos raidą Vilniuje bei kitose LDK vietovèse iki XVI a. vidurio kreipdamas dėmesị ị špitolių fundacijas. Tokios įstaigos turejjo tikslą - rūpintis varguolių ir neturtingų visuomenès narių sveikata bei gerove ir tuo būdu gelbèti dievobaimingų globejų vardus nuo užmaršties. 1518-1522 m. pirmają Vilniaus špitolę - pavadintą tradicinių globejų šv. Jobo ir Marijos Magdalietės vardu - fundavo Vilniaus katedros kanauninkas bei gydytojas Martynas Dušnikietis, remiamas valdovo Žygimanto Senojo bei Ponų Tarybos. Špitolè netrukus tapo sudètine Vilniaus miesto sakralinès topografijos dalimi, o jos pavyzdi imitavo stačiatikių bei kitų konfesijų bendruomenès. Straipsnio priede publikuojami dvylikos fundacijų tekstai. 